поставки продукции, производства, хранения, транспортировки и реализации продовольственного сырья и продуктов и т.д.

Кроме того в число рассматриваемых мер пресечения относятся отстранение от работы граждан, являющихся носителями возбудителей инфекционных болезней и могущих быть источниками их распространения; обязательная госпитализация и изоляция (карантин) инфекционных больных и граждан с подозрением на инфекционное заболевание, представляющих опасность для окружающих.

В целях пресечения правонарушений в области финансов и кредита, обеспечения финансовой дисциплины применяются меры финансово - кредитного характера (к примеру - изъятие (взимание) в доход бюджета сумм, полученных предприятиями, учреждениями и организациями путем нарушения финансовой дисциплины).

Подводя итог рассмотрения мер пресечения, можно констатировать, что меры административно-правового пресечения - это регламентируемые нормами административного права средства принудительного воздействия, применяемые уполномоченными на то органами государственной власти и их должностными лицами, которые направлены на прекращение противоправного деяния, устранение вызванных им вредных последствий для личности, общества и государства, а также на создание оптимальных условий для последующего привлечения виновных лиц к соответствующему виду юридической ответственности.

Система мер пресечения чрезвычайно разнообразна. Вследствие этого многими правоведами не раз проводилась попытка систематизации и классификации различных мер пресечения в родовые группы.

В случае неэффективности общих мер пресечения допускается применение в соответствии с законом специальных мер административного пресечения.

Кроме того хотелось бы еще раз отметить, что при изменении мер пресечения, как и во всей своей деятельности, субъекты власти должны строго соблюдать принципы законности и целесообразности, а также минимизации вреда: избирать такие средства, которые максимально необходимы для предотвращения вредных последствий. Во всех случаях должно соблюдаться необходимое соответствие между избранной мерой принуждения, характером нарушения и, конечно, требованием правовых норм.

$$
* * *
$$

1. Бахрах Д. Н. Административное право России: учебник для вузов / Д. Н. Бахрах. - М., 2015. - 890 c.

2. Копытов Ю.А. Административное право: учебник / Ю.А.Копытов. - Москва: Юрайт, 2018. - 645 с.

3. Коренев А.П. Административное право России: Часть общая. М., 2011. С.196.

4. Мигачев Ю. И. Административное право Российской Федерации: учебник / Ю. И. Мигачев. - М., 2017. $-600 \mathrm{c}$.

5. Попов Л. Л. Административное право России: учебник / Л. Л. Попов. - 3-е издание, переработанное и дополненное. - М., 2017. - 850 с.

\title{
Ёркина Т.H. \\ Проблемные аспекты правового регулирования правил поведения судьи во внесудебной деятельности
}

ФГБОУ ВО «Елецкий государственный университет им. И.А. Бунина»

(Россия, Елеи)

doi: $10.18411 / l j-02-2021-204$

idsp: ljournal-02-2021-204

\section{Аннотация}

Статья посвящена проблемам правового регулирования правил поведения судьи во внесудебной деятельности. Автор поставила задачу провести комплексный анализ 
таких правил, рассмотреть на примерах из практики, выявить проблемы и предложить возможные пути их решения. В работе проанализированы современное законодательство, судебная практика и выделены основные проступки судьи во внесудебной деятельности, которые могут умалять авторитет судебной власти. Делается вывод, что на практике основанием для увольнения судьи чаще становится именно внесудебная деятельность, которая умаляет авторитет судебной власти и статус судьи.

Ключевые слова: судья, профессиональная этика судьи, Кодекс судейской этики, внесудебная деятельность, дисциплинарный проступок, досрочное прекращение полномочий.

\section{Abstract}

The article is devoted to the problems of legal regulation of the rules of conduct of a judge in non-judicial activities. the author has set the task to conduct a comprehensive analysis of such rules, to consider them on practical examples, to identify problems and to suggest possible ways to solve them. the paper analyzes the current legislation, judicial practice and highlights the main offenses of a judge in extra-judicial activities, which may detract from the authority of the judiciary. it is concluded that in practice, the basis for the dismissal of a judge is more often non-judicial activity, which detracts from the authority of the judiciary and the status of a judge.

Keywords: judge, professional ethics of a judge, Code of Judicial Ethics, extrajudicial activity, disciplinary offense, early termination of powers.

В настоящей статье мы рассмотрим основные требования к поведению судьи во внесудебной деятельности, т.к., по нашему мнению, именно данная область наименее конкретизирована в правовом поле.

Правовое регулирование основных требований к внеслужебному поведению судьи осуществляется следующими нормативно-правовыми актами:

1) Закон РФ от 26.06.1992 г. № 3132-1 «О статусе судей в Российской Федерации». Так, ч. 2 ст. 3 и ст. 12.1 Закона закрепляют, что судья во внеслужебных отношениях должен избегать всего того, что может умалить авторитет судебной власти, а за совершение дисциплинарного поступка на судью может быть наложено дисциплинарное взыскание в виде: замечания, предупреждения, понижения в квалификационном классе, досрочного прекращения полномочий судьи [1]. Следует отметить, что понижение в квалификационном классе как вид дисциплинарного взыскания за вышеуказанные проступки был добавлен в Закон в июле 2018 г.

При наложении дисциплинарного взыскания, конечно, учитываются многие факторы: от характера поступка до его последствий и проч. Также в Законе даётся разъяснение, какой вид дисциплинарного взыскания можно применить в том или ином случае. Например, замечание - при малозначительности поступка, предупреждение при совершении дисциплинарного проступка, понижение в квалификационном классе при существенном нарушении положений Закона о статусе судей, а досрочное прекращение полномочий - за существенное, виновное, несовместимое с высоким званием судьи нарушение положений законодательства.

2) Кодекс судейской этики: утв. VIII Всероссийским съездом судей 19.12.2012, который, в большей степени, конкретизирует общие принципы осуществления внесудебной деятельности и устанавливает правила в отдельных областях внесудебной деятельности и соответствующие ограничения в связи с этим [2]. В ч. 1 ст. 1 закреплено, что устанавливаются обязательные для каждого судьи правила поведения при осуществлении профессиональной деятельности и во внесудебной деятельности, основанные на высоких нравственно-этических требованиях, 
положениях законодательства России, международных стандартах в сфере правосудия и поведения судей. В этой же статье поясняется, что повышенные нравственноэтические требования к судье, связанные с его статусом, не должны расцениваться как ограничение общегражданских прав и свобод, гарантируемых Конституцией России.

Проведя анализ содержания статей Кодекса судейской этики (ст.ст. 4, 6, 14-16, 19-23), можно сделать вывод, что в нём закреплены не только общие требования по внесудебной деятельности, но и ограничения, связанные с отдельными возможными ситуациями во внесудебной деятельности.

В Кодексе судейской этики 2012 года были закреплены важные базовые принципы: следование судьёй профессиональной этике, закрепление стандартов поведения судей, государственные гарантии и социальное обеспечение, которые направлены на достижение целей правосудия - вынесения законных, обоснованных и справедливых судебных решений. По оценке С.В. Мельника, который исследовал проблематику нравственных основ осуществления правосудия по гражданским делам, принятие Кодекса стало новым этапом совершенствования правил этики судейского сообщества, причём с учётом международных стандартов [3].

Такими международными стандартами явились Бангалорские принципы поведения судей, принятые в 2006 году Резолюцией Экономического и Социального Совета ООН [4]. Некоторые государства участвовали в подготовке данных Принципов, но в дальнейшем этот документ стал практически эталоном для разработки собственных нравственных принципов поведения судей во многих странах, а также получил высокую оценку от различных международных организаций и самого судейского корпуса. В России пошли по пути взятия за образец основных положений Бангалорских принципов.

В 2016 году Верховный Суд Российской Федерации издал соответствующий Пленум, который разъяснил некоторые вопросы применения законодательства в сфере дисциплинарной ответственности судей. П. 8 Постановления закрепил, что «дисциплинарное взыскание в виде досрочного прекращения полномочий может применяться к судье ... за совершенное однократное грубое нарушение при исполнении им служебных обязанностей либо во внеслужебной деятельности, которое дискредитирует судебную власть, причиняет ущерб репутации судьи и несовместимо с его статусом судьи» [5].

Если обратиться непосредственно к примерам из судебной практики, то большинство из них (по поведению судьи во внеслужебной деятельности) - это совершение различных проступков в состоянии алкогольного опьянения, конфликтные ситуации с окружающими, например, соседями, поддержание дружеских отношений либо с лицами, ранее судимыми, либо с адвокатами, которые потом часто представляют интересы одной из сторон в процессе, где заседает данный судья, использование своего служебного положения в личных целях и проч.

В последнее время участились также случаи недостойного поведения судей, связанного с социальными сетями, Интернетом, что также становится предметом жалоб и разбирательства в квалификационных коллегиях судей, с последующим вынесением решений. Так, размещение судьёй П. в свободном доступе на своей странице в социальной интернет-сети «Одноклассники» фотографий с её изображением в зале судебного заседания на фоне символов государственной власти Российской Федерации с различными предметами и комментариями некорректного содержания, а также в непристойном для судьи положении, что вызвало досрочное прекращение полномочий судьи П. 
Однако, работа по совершенствованию содержания и разъяснения требований, предъявляемых к судьям в плане их профессиональной этики, ведётся, даются соответствующие разъяснения, методические рекомендации.

Так, например, есть Заключение Комиссии Совета судей РФ по этике от 05.12.2018 г. № 15-КЭ, которое устанавливает основы реализации права судьи на вхождение в состав правления садоводческого некоммерческого товарищества на безвозмездной основе [6], а также Методические рекомендации по реализации квалификационными коллегиями судей норм законодательства Российской Федерации о противодействии коррупции [7]. В данных Методических рекомендациях приведены случаи несоблюдения судьями требований антикоррупционного законодательства, а также, какие дисциплинарные взыскания к ним были применены. Например, замечание было объявлено за использование судьёй служебного бланка вне рамок служебной деятельности в целях помощи своим родственникам; предупреждение - когда судья допустил внепроцессуальное общение с потерпевшим и его представителем; досрочное прекращение полномочий - когда судья допустил внепроцессуальное общение с подсудимым.

Таким образом, учитывая вышеизложенное, можно отметить, что наиболее оспариваемым основанием увольнения судьи является увольнение за дисциплинарное взыскание (но оспорить такие увольнения практически не удаётся), причём основанием чаще становится именно внесудебная деятельность, которая умаляет авторитет судебной власти и статус судьи. Наибольшее количество споров с судьями связано с прекращением отставки за неэтичное поведение судьи в отставке, а не с досрочным прекращением полномочий действующего судьи (в оспаривании также не удаётся добиться успеха).

Требуется дальнейшая модернизация организационно-правового механизма дисциплинарной ответственности судей и разработка формулы дисциплинарного проступка судьи, чтобы не было расхождений в судейском усмотрении по вопросам решения, можно ли считать проступок судьи умаляющим авторитет судебной власти.

$$
* * *
$$

1. О статусе судей в Российской Федерации: Закон Российской Федерации от 26.06.1992 г. № 3132-1 с изм. и доп. на 08 декабря 2020 г. // Российская газета. - 1992. - 29 июля; 2020. - 10 декабря.

2. Кодекс судейской этики: утв. VIII Всероссийским съездом судей 19.12.2012 г. (ред. от 08.12.2016) // Бюллетень актов по судебной системе. - 2013. - № 2. [Электронный ресурс] // Режим доступа: http://www.consultant.ru/document/cons_doc_LAW_139928/(дата обращения: 30.12.2020 г.)

3. Мельник С.В. Нравственные требования к деятельности судебной власти: международные принципы и национальное регулирование / С.В. Мельник // Вестник Московского университета МВД России. -2018. - № 2. - С. 215-218.

4. Бангалорские принципы поведения судей: приняты 27.07.2006 г. Резолюцией 2006/23 Экономического и Социального Совета $\mathrm{OOH}$ «Укрепление основных принципов поведения судей» [Электронный ресурс] // Режим доступа: URL: // https://base.garant.ru/2565640/ (дата обращения: 30.12.2020 г.).

5. О судебной практике применения законодательства, регулирующего вопросы дисциплинарной ответственности судей: Постановление Пленума Верховного Суда Российской Федерации от 14 апреля 2016 г. № 13 // Российская газета. - 2016. - 27 апреля.

6. О праве судьи, судьи в отставке входить в состав правления садоводческого некоммерческого товарищества на безвозмездной основе: Заключение Комиссии Совета судей РФ по этике от 05.12.2018 N 15-КЭ [Электронный ресурс] // Режим доступа: URL: // https://www.garant.ru/products/ipo/prime/doc/72031896/ (дата обращения: 30.12 .2020 г.).

7. Методические рекомендации по реализации квалификационными коллегиями судей норм законодательства Российской Федерации о противодействии коррупции: утв. решением Высшей квалификационной коллегией судей РФ от 26.01.2017 (ред. от 21.09.2018) (вместе с «Основными требованиями (ограничения, запреты, обязанности) к судьям в целях противодействия коррупции») // Режим доступа: URL: // https://legalacts.ru/doc/metodicheskie-rekomendatsii-porealizatsii-kvalifikatsionnymi-kollegijami-sudei-norm-zakonodatelstva/ (дата обращения: 30.12 .2020 г.). 